\title{
ROLE OF TEENAGERS ATTITUDE AND INTENTION IN BUYING TRADITIONAL BALINESE FOOD INNOVATION WITH CUSTOMER ORIENTATION
}

\author{
Rastini Ni Made, Nurcaya Nyoman, Kumala Anak Agung Wulan, Mila \\ Faculty of Economics and Business, University of Udayana, Bali, Indonesia \\ `E-mail: nimaderastini@yahoo.co.id
}

\begin{abstract}
This research was conducted considering the rise of the culinary industry, especially those serving fast food, almost all regions of Indonesia, especially in Bali. Fast food has been very popular among the people, especially for the younger generation. This study aims to explain the attitudes, subjective norms and their influence on adolescent buying intentions of traditional Balinese foods that have innovated with customer orientation. To achieve this goal 200 respondents in the areas of Denpasar, Badung, Gianyar and Tabanan are used by purposive sampling with questionnaires as a method of collecting data. Data were analyzed using Reasoned Action models and regression analysis. The variables measured from the sample members consisted of evaluations of beliefs, subjective norms and their influence on adolescent buying intentions of traditional Balinese food with customer-oriented innovation. The results of the analysis show that in general the attitude of adolescents was confident and even strongly convinced of the existence of traditional Balinese foods as measured by evaluating the beliefs of traditional Balinese food attributes. From the regression analysis it is also known that subjective attitudes and norms significantly influence adolescent buying intentions of traditional Balinese food with customer-oriented innovation. The strategic implication of this research is that traditional Balinese food businesses should pay more intensive attention to the reference group because it can influence adolescent buying intentions of traditional Balinese food. Thus traditional Balinese food can still survive with its uniqueness in the midst of globalization.
\end{abstract}

\section{KEY WORDS}

Evaluation of beliefs, purchase intentions, subjective norms.

Entering the era of globalization and the development of information technology is a challenge for business people in almost all industries. Advances in information technology also have an impact on the socio-cultural shift inherited by the ancestors of a nation. As a result of this cultural shift, many young people prefer Western culture to traditional culture. That is because the mindset of those who consider western culture more modern and more popular, so that their awareness in preserving traditional culture decreases. One effect that can be felt is the shifting of the level of consumption of traditional foods which most people have begun to forget. People now prefer foods that are trending, namely fast food with modern packaging that is unique and attractive. In this modern era that is very practical, the choice of food is very diverse. One option for urban people who are busy with activities is to choose to eat modern food (fast food) (Mufidah, 2012: 2). Fast food is a type of food that is available in a fast and ready to eat form, such as fried chicken, hamburger, and pizza. Since it's easy to get fast food on the market, the availability of food variations according to taste and purchasing power, and its processing and preparation are faster, it is suitable for those who are always busy (Sulistijani, 2002). The phenomenon of fast food or modern food can also be seen from the emergence of various fast food shops on the roadside. Even for now rarely found a restaurant that sells traditional food. This is because there has been a reduction in people's interest in consuming traditional food because it is considered impractical. Especially for teenagers tend to prefer to consume modern food.

Traditional food is formed by a process of development that runs for years, namely the process of adjusting between the food consumed with the types of food available and the forms of activities carried out by the local community. According to Sastroamidjojo in Eliazer 
in 2013 traditional foods are foods that have been eaten for generations, consisting of dishes that are suitable to taste, do not conflict with religion, local community beliefs and are made from food ingredients and spices available locally. Given the cultural value inherent in these traditional foods, various efforts need to be maintained in the midst of the many offers of fast food lately and in the future.

Based on interviews conducted with several teenagers in Denpasar and surrounding areas, there are still many of them who like traditional Balinese food, not only from the lower middle class but also the upper class. from its shape and taste. But according to the name, most of these traditional foods do not last long with very limited time and place of sale, so the opportunity to capture potential market opportunities is less than optimal.

Observing this situation the traditional Balinese food Traders are accompanied by the provincial government of Bali through working instruments related to intense activities to restore the existence of traditional Balinese food. Activities that have been carried out are traditional food festivals or exhibitions and assistance in order to develop innovations for the business. The purpose of this activity is to introduce the existence of traditional Balinese food and at the same time develop new innovations in accordance with the needs of the current target market, especially teenagers. Thus it is expected that traditional food as one of the cultural assets of Bali can still be preserved.

Attitude is defined as a positive or negative feeling someone to do certain behaviors (Davis, 1989). Trust in various information will result in a good attitude by mobile banking users which will improve attitude indirectly. In this study, constructs of attitude are defined as positive or negative feelings of mobile banking users as indicated by someone's likes or dislikes towards mobile banking (Arthana \& Rukhviyanti, 2015). Several previous studies conducted by Nasri \& Charfeddine (2012) showed a significant relationship between attitude and interest in using internet banking. The study is in line with research conducted by Kurniawan et al., (2013) the results show that the user's attitude gives a positive influence on the interest in using mobile banking services. In contrast to research conducted by previous researchers, Taylor \& Todd (1995) states that attitudes have no influence on behavioral interest for both groups of users, both experienced and inexperienced groups.

Azjen (1988) defines subjective norms as a person's perception of social pressure to do or not do behavior. Subjective norms refer to individual subjective judgments about other people's preferences and support for a behavior. Various empirical studies examining the construct of subjective norms in research related to information technology have been conducted by previous researchers. Previous research conducted by Mas'ud (2012) shows that subjective norms have a positive effect on customer interest in using ATMs. In contrast to the results of these studies, research conducted by Juwaheer et al., (2012) did not provide similar results. The research is in line with research conducted by Oktapiani (2017), showing that subjective norms do not significantly influence the behavioral interest in using technology. Based on the results of research that are inconsistent between previous researchers with other researchers, the researchers are interested in re-examining the influence of subjective norms on individual interests using mobile banking. Based on these thoughts, the following hypotheses can be proposed:

The effect of attitude on individual behavior interests:

$\mathrm{H}_{0}$ : Attitude does not have a positive and significant influence on consumer behavior;

$\mathrm{H}_{1}$ : Attitude has a positive and significant influence on consumer behavior interests.

The effect of subjective norms on individual behavior interests:

$\mathrm{H}_{0}$ : Perceptions of subjective norms do not have a positive and significant influence on consumer behavioral interest in this case adolescent buying intentions;

$\mathrm{H}_{1}$ : Perceptions of subjective norms have a positive and significant influence on consumer behavior interests.

\section{METHODS OF RESEARCH}

Judging from the nature of the problem, this research is associative in nature, which aims to explain the influence of the variable attitudes and subjective norms of adolescents on 
traditional food purchase intentions with customer-oriented innovation in the Sarbagita region of Bali Province. Judging from the nature of the problem, this research is associative in nature, which aims to explain the effect of variable attitudes and subjective norms of adolescents on traditional food purchase intentions with customer-oriented innovation in the Sarbagita region of Bali Province. The study population was all adolescents in the Denpasar Badung, Gianyar and Tabanan Bali Provinces. The number of samples used in this study were 200 respondents because they met the requirements to be able to use Maximum Likelihood (M) as an estimation model. In taking the sample in this study non-probability sampling techniques are used, which are sampling techniques that do not provide equal opportunity or opportunity for each element or member of the population to be selected as a sample. The sampling technique in question is Purposive Sampling, which is a sampling technique with certain criteria. Data analysis techniques used are descriptive statistical analysis and inferential statistics.

\section{RESULTS AND DISCUSSION}

This Regression Analysis is used to determine the effect of consumer attitudes (evaluations of beliefs) and subjective norms (normative beliefs and motivations) on teenage purchase intentions of traditional Balinese food with customer-oriented innovation. The summary of the regression analysis is presented in Table 1 below:

Table 1 - Regression Analysis Result

\begin{tabular}{|c|c|c|c|c|c|}
\hline Variable & Unstandardized coefficients(B) & Std Error & $\begin{array}{c}\text { Standardized coefficients } \\
(\text { Beta })\end{array}$ & $\mathrm{t}$ & Sig. \\
\hline Attitude & 0.391 & 0.708 & 0.315 & 4.999 & 0.000 \\
\hline Subjective Norms & 0.649 & 0.077 & 0.530 & 8.414 & 0.000 \\
\hline Constant $=-0.051 ; \mathrm{R}=0.787 ;$ R square $=0.619 ; \mathrm{F}$ hitung $=160.038 ;$ Sig. $=0.000$ \\
\hline
\end{tabular}

Based on Table 1 it can be seen the resulting regression equation as follows:

$$
Y=-0.051+0.391 X 1+0.649 X 2
$$

From the regression analysis it can be explained that the purchase intention of adolescents towards traditional Balinese food with customer-oriented innovation is influenced by attitude (evaluation of belief attributes) and subjective norms of consumers with a value of $\mathrm{R}$ square $=0.619$. This means that the attitude variable and subjective norm variable are able to explain the dependent variable in terms of adolescent buying intentions of traditional Balinese food with customer-oriented innovation of 61.9 percent while the remaining $38.1 \%$ is explained by other variables not discussed in this study. The calculated $F$ value of 160.038 at the significance level $\alpha<0.001$, when compared with the value of $F$ Table $=2.68$ calculated $F$ value $\mathrm{F}$ table) this means that the attitude variable and subjective norm variables together have a significant influence on adolescent purchase intentions towards food traditional Balinese with customer-oriented innovation.

From the beta value in the analysis it is known that consumers, in this case adolescents, are motivated to buy traditional foods with customer-oriented innovation after receiving encouragement from the family (subjective norms) with a value of 0.530 , as well as an evaluation value on the belief that Balinese traditional food attributes are positive. This indicates that adolescents have a positive attitude towards innovation that has been carried out by traditional Balinese culinary entrepreneurs.

Subjective norm variables (family suggestions and motivation to follow those suggestions) have a calculated $t$ value with a greater significance than the $t$ value for attitudes $(8,414>4,919)$. Thus it can be said that subjective norms have a more dominant influence compared to attitude variables in influencing adolescent's intention to buy traditional Balinese food with customer-oriented innovation. This situation is reasonable because families who encourage teenagers to buy traditional foods that have recently made 
innovations tend to interact more often in markets or traditional traders who are offering traditional Balinese food. From the value of $t$ for the variable attitudes and subjective norms it can also be concluded that subjective attitudes and norms have a positive and significant influence on consumer behavior in this case adolescent buying intentions of traditional Balinese food with customer-oriented innovation. This statement indicates that Ho was rejected and $\mathrm{Hi}$ was accepted, meaning that it was in line with previous research.

\section{CONCLUSION}

Based on the results of the analysis on the previous chapter, it can be concluded as follows: Variable of consumer attitudes measured from beliefs and evaluations of traditional Balinese food attributes with customer-oriented innovation in general is very high especially indicators of ease of obtaining such traditional food, especially in the area of the respondent's residence. Likewise, consumers have high confidence and evaluation of the indicators of traditional Balinese food, which always follows the changing times. Consumer subjective norm norms in this case the family's recommendation can motivate consumers in this case adolescents to follow the advice of buying traditional Balinese food with customer-oriented innovation because the price is cheaper than fast food to get the fulfillment of needs with the same level of satisfaction.

From the regression analysis, it can be explained that jointly the attitude variable and subjective norms influence the adolescent buying intentions of traditional Balinese food with customer-oriented innovation, where the subjective norm variable is more dominant in influencing the decision compared to the teenage attitude variable itself. This indicates that the greater the adolescent family's recommendations, the higher the intention to buy the food in question because the adolescent's own attitude is actually positive.

In order to survive in the era of globalization, it is suggested things like the following, for traditional Balinese food entrepreneurs should offer a variety of sizes or packaging so that consumers can choose according to their needs without the need to wait a long time to get the packaging in accordance with what they want. Thus consumers feel buying traditional Balinese food is a very appropriate action because it is more effective and efficient. Traditional Balinese food entrepreneurs should still maintain the natural ingredients used in the production of these foods, because today's society especially teenagers have a high understanding and orientation towards health. With the commitment of the entrepreneurs it is believed that traditional Balinese food will continue to survive with its uniqueness in the era of globalization. Family recommendations are the dominant variable influencing purchase intentions in this study, so traditional Balinese food entrepreneurs or traders should provide services and intensively communicate with real customers because they can provide creative ideas to traders or entrepreneurs and can simultaneously influence or provide suggestions to the other party to buy the traditional Balinese food.

\section{REFERENCES}

1. Ajzen, I. 1991. The Theory of Planned Behavior. Organizational Behavior And Human Decision Processes, 50, Pp: 179-211.

2. Arthana, Yudhi W,.dan Rukhviyanti, R. Novi.2015. Pengaruh Minat Individu Terhadap Penggunaan Mobile banking (M-Banking): Model Kombinasi Technology Acceptance Model (TAM) and Theory of Planned Behavior (TPB). Jurnal Informasi, 7 (1), Pp : 25-44

3. Bilson Simamora. 2004. Panduan Riset Perilaku konsumen, Jakarta. Penerbit Gramedia Pustaka Utama.

4. Davis, F.D. 1989. Perceived Usefulness, Perceived Ease Of Use, And User Acceptance Of Information Technology. Mis Quarterly,13 (3) Pp: 319-340.

5. Fishbein, M., and Ajzen, I. 1975.Belief, Attitude, Intentions and Behaviour: An Introduction To Theory And Research. Addison-Wesely. Boston. Ma.

6. Hartono, Jogiyanto. 2007. Sistem Informasi Keperilakuan. Yogyakarta: Andi. 
7. Juwaheer,Thanika Devi., Sharmila Pudaruth., and Priyasha Ramdin.2012. Factors Influencing the Adoption of Internet Banking: A Case Study Of Commercial Banks In Mauritius. World Journal of Science, Technology And Sustainable Development, 9 (3), Pp. 204-234.

8. Kurniawan. I Putu. 2003. Sikap and Perilaku Nasabah Terhadap Penetapan On-Line System pada PT Bank Buana Indonesia Cabang Denpasar. Tesis. Fakultas Ekonomi Universitas Udayana.

9. Mas'ud, Muchlis H. 2012.Pengaruh Sikap, Normas-Norma Subjektif and Kotrol Perilaku Yang Mempersepsikan Nasabah Bank Terhadap Keinginan Untuk Menggunakan Automatic Teller Machine (Atm) Bank Bca Di Kota Malang.Jurnal Manajemen and Akuntansi, 3(3), Pp: 13-28.

10. Mowen. J. C and Michael Minor. 2002. Perilaku Konsumen. Jilid 1. Jakarta : Penerbit Erlangga.

11. Nasri, Wadei., and Charfeddine, Lanouar. 2012. Factors Affecting Adoption of Internet Banking In Tunisia: An Integration Theory Of Acceptance Model And Theory of Planned Behavior. Journal Of Techonology Management Research 23, Pp 1-14.

12. Oktapiani, Renny.2017. Interpretasi Model Penerimaan Sistem Ujian Online Dengan Pendekatan TechnologiAcceptance Model (TAM) and Theory PlannedOf Behavior (TPB) Di Smk Pasim Plus Kota Sukabumi. Swabumi, 5, Pp. 98-107.

13. Putri, Ni Made Kania Indriani.,danSuprapti, N.W.S. 2016. Aplikasi Model Tam dalam Menjelaskan Niat Menggunakan Mobile CommerceDi Kota Denpasar. E-Jurnal Manajemen Unud, 5 (4), 2341-2368.

14. Sulistiyarini, Suci. 2012. Pengaruh Minat Individu Terhadap Penggunaan Mobile banking: Model Kombinasi Technology Acceptance Model (Tam) and Theory of Planned Behavior (Tpb). Jurnal Ilmiah Mahasiswa Fakultas Ekonomi and Bisnis Universitas Brawijaya.

15. Sugiyono, 2014, Metode Penelitian Bisnis. Bandung: Alfabeta.

16. Taylor, S. And Todd, P.A. 1995. "Understanding Information Technology Usage: A Test Of Competing Models", Information Systems Research, 6 (2), Pp. 144-76. 